\title{
THE EFFECTIVENESS OF PEER FEEDBACK TECHNIQUE TO TEACH WRITING VIEWED FROM STUDENTS' CREATIVITY
}

\author{
Andianto \\ Muhammadiyah Univeristy of Metro
}

\begin{abstract}
The objectives of the research are to examine whether: (1) Peer Feedback Technique is more effective than Teacher Feedback Technique to teach writing for the tenth grade students of SMA Muhammadiyah 1 Metro; (2) the students having high creativity have better writing ability than those having low creativity for the tenth grade students of SMA Muhammadiyah 1 Metro; and (3) there is an interaction between teaching techniques and students' creativity to teach writing for the tenth grade students of SMA Muhammadiyah 1 Metro. The method applied in this research was an experimental study. It was conducted at the tenth grade students of SMA Muhammadiyah 1 Metro. It consists of six classes. The Samples were two classes of six classes chosen by using cluster random sampling. Each class was divided into two groups (the students having high and low students' creativity). The data were analyzed by using Multifactor Analysis of Variance (ANOVA) test of $2 \times 2$ and Tuckey test. Based on the data analysis, there are some research findings that can be drawn. They are (1) Peer Feedback Technique is more effective than Teacher Feedback Technique to teach writing for the tenth grade students of SMA Muhammadiyah 1 Metro; (2) the students having high creativity have better writing ability than those having low creativity; (3) there is an interaction between teaching techniques and students' creativity to teach writing in which Peer Feedback Technique is more appropriate to teach writing for students having high creativity and Teacher Feedback Technique is more appropriate to teach writing for students having low creativity. In short, the effect of teaching technique depends on students' creativity.
\end{abstract}

Keywords: peer feedback technique; teacher feedback technique; writing ability; creativity; experimental study.

\section{Introduction}

The general aim of teaching English based on Kurikulum Tingkat Satuan Pendidikan (KTSP) is to develop students' communicative competence of the four language skills or aspects of teaching and learning; listening, speaking, reading, and writing (Depdiknas; 2005: 171). Among the four language skills mentioned above, writing is one of essential parts to be able to communicate in target language. Writing also plays a very significant role in the success of learning. Therefore, it is not surprising in Indonesia that writing has been paid more attention to the government.

The attention of the government to the writing can be seen from our curriculum that puts a strong emphasis in writing. Consequently, the basic competence of writing that should be learned by the students in senior high school is expressing the meaning in written functional text and write simple essay in form of procedure, descriptive, recount, narrative, report, news item, analytical exposition, hortatory exposition, spoof, explanation, discussion and review. Based on the basic competence that students have to master in senior high school, it indicates that students are expected to be able to write different text types.

Writing is a difficult activity for most students, both in the mother tongue and in a foreign language especially English. Murcia (2000: 161) states that writing skill is often perceived as the most difficult skill since it requires a higher level of productive language control than other skills. It is no wonder that EFL students think that writing is a difficult skill to be mastered because it requires many aspects of language in its 
production such as organization, content, language use, mechanic and vocabulary. Moreover, writing is a complex process and commonly difficult for most people.

In line with this difficulty, Byrne (1997:4) underlines that there are three major problems that cause writing become a difficult activity. There are psychological problem, linguistic problem, and cognitive problem. Psychological problem is the essential of writing activity which is a solitary activity without the possibility of interaction or the benefit of feedback. It is different from speech which gets feedback from someone physically present. This makes writing become a hard activity to be required. The next problem related to linguistic problem is that the coherency, the choice of sentence structure and the way our sentences are linked together and sequenced. It is the hard steps to be implemented by the writers. The last problem related to the cognitive problem is the process of instruction in learning writing needing much effort. Such as learning the written form of the language, learning the certain structures which are less used in speech, and learning to organize the ideas in a well form of writing. Finally, writing can be said as a task which is often imposed on some people by the circumstances. This not only has psychological effect in writing process, it is also caused a content problem which makes writing become more difficult to be acquired.

Compared to the other skills, writing is considered the most complicated one for the students to master. Students and teachers have long knowledge that learning to write in English is a complex process. In addition to linguistics problems, there are a lot of difficulties associated with written frameworks and rhetorical conventions. The ability to produce a good piece of writing is facilitated by the ability to write correct sentences and by the ability to connect sentences to present unified thought in written discourse. In short, students should master the rules and elements of writing to achieve successful communication in written language.

As mentioned before, there is no doubt that writing is the most difficult skill for learner to master. To solve the problems and difficulties as mentioned above, English teachers are expected to be able to use an interesting technique. The teachers' techniques to teach writing are important factors that may affect the students' ability in writing. There are some kinds of techniques that can be applied by the English teachers to develop their students' ability in writing. One of techniques that can be used in teaching writing is peer feedback, a kind of technique of collaborative learning technique (CoLT) focusing on writing.

Feedback is advice, criticism or information about how good or useful something or somebody work is. Ur (1996: 242) defines feedback as information that is given to the learner about his or her performance of the learning task, usually with the objective of improving their performance. Feedback is an important aspect to develop students' language awareness so that they can perform affectively in the writing classroom. In ESL teaching, feedback on students' writing is also judged as an important aspect. The goal of feedback is to teach skills that help students improve their wiring proficiency to the point where they are cognizant of what is expected of them as writer and are able to produce it with minimal errors and maximum clarity. Feedback given to the students will make them realize and understand their deficiency in writing so that they can improve their writing.

Peer feedback is an interactive process of reading and commenting on a classmate's writing (Oshima and Hogue; 
2007: 194). In this technique, the student pairs critically review and provide editorial feedback on each other's writing assignments. Peer feedback helps teach students how to identify the features of good and poor writing in the work of others, thus developing critical evaluation skills that they can apply to their own writing (Barkley, Cross \& Major ; 2005: 251).

According to Lee (2009: 130) peer feedback activities tend to generate more comments on the content, organization, and vocabulary. This means that peer feedback is not only about how a student makes correction on his or her friend's writing, but it is also about how a students' criticism, suggestion, and point of view generate meaningful improvement toward other students' writing. Based on explanation above, this technique allows the students to help to improve, correct and edit students' writing related to writing contents, organizational patterns, grammatical structures and appropriate word choice. Another feedback that can be used to respond students writing is teacher feedback. This technique is usually use by the teacher in responding students writing. This technique is also used by the teacher of SMA Muhammadiyah 1 Metro. Therefore, this technique was used by researcher to compare peer feedback technique.

Another factor that also determines the success of teaching writing is the students' creativity. Creativity plays an important role to produce a good and understandable writings. In the classroom, there are students who have high creativity and low creativity. Their creativity can appear when they produce or apply something new such as writing activities. Creativity is the activity to convey something new. In other words, creativity involves thinking that is aimed at producing ideas or products that are relatively novel and that are, in some respect, compelling (Kaufman and Sternberg, 2006: 2). According to Jones and Wyse (2004: 20) the composition of writing usually requires considerable amounts of creativity. It indicates that creativity is an important aspect needed to produce writing form. The Students' level of creativity determines their writing ability. The students who have high creativity can produce a writing form easily than the low one.

Considering that background, the objectives of this research are to find out whether: (1) Peer Feedback Technique is more effective than Teacher Feedback Technique to teach writing for the tenth grade students of SMA Muhammadiyah 1 Metro; (2) The students having high creativity have better writing ability than those having low creativity for the tenth grade students of SMA Muhammadiyah 1 Metro; (3) There is an interaction between teaching techniques and students' creativity to teach writing for the tenth grade students of SMA Muhammadiyah 1 Metro.

Based on the background and objective of the study above, the writer formulates the hypothesis of the research. They are: 1) Peer Feedback Technique is more effective than Teacher Feedback Technique to teach writing for the tenth grade students of SMA Muhammadiyah 1 Metro; 2) the students having high creativity have better writing ability than those having low creativity for the tenth grade students of SMA Muhammadiyah 1 Metro; 3) there is an interaction between teaching techniques and students' creativity to teach writing for the tenth grade students of SMA Muhammadiyah 1 Metro.

\section{Review Of Related To Literature}

There are several definitions of writing that explained by several experts. Byrne 
(1997:1) stated that the purpose of writing is to produce the complete text. In his book, "Teaching Writing Skills", he propose that writing is an activity of producing a sequence of sentence arranged in a particular order and linked together in certain ways and it should be a coherent text. According to Spartt (2005: 26) writing is one of the four language skills that involve communicating a message (something to say) by making signs on a page. In addition, writing is activity in which learners form graphic symbols, arrange them to form words, and put the words in order and link them together in a certain way to produce a logical sequence of sentence (Hernowo, 2004: 43).

In line with those definition, Nunan (2003: 88) defines that writing is the process of thinking to invent ideas, thinking about how to express into good writing, and arranging the ideas into statement and paragraph clearly. It indicates that the learners are expected to explore the ideas and make them into good paragraph. Moreover Nunan (1999: 3 ) adds that successful writing involves mastering the mechanics of letter formation and obeying conventions of spelling and punctuation, using grammatical system to convey one's intended meaning, organizing content at the level of paragraph and the complete text to reflect given/ new information and selecting an appropriate style for one's audience.

From the definition of writing above, it can be concluded that writing is the way to produce the language into written form in a sequence of sentence by combining the writing elements including control of content, spelling and punctuation, vocabulary, and integrating information into cohesive and coherent paragraph in order to make grammatical correct sentence for the purpose of communication.
Providing feedback is often seen as one of the ESL writing teacher's most important tasks (Hyland; 2003: 177). It indicates that feedback is an essential component of any English language writing course. In line with Hornby, Ur (1996: 242) defines feedback as information that is given to the learner about his or her performance of the learning task, usually with the objective of improving their performance. Moreover, according to Keh (1989: 18), feedback refers to any input when provides information for revision from reader to writer.

Peer feedback is referred to by many names, for example, peer response, peer editing, peer critiquing and peer evaluation (Keh; 1990: 295). Similar to its names, researcher also tries to define peer feedback in a different way. Peer feedback is an interactive process of reading and commenting on a classmate's writing (Oshima and Hogue; 2007: 194). According to Flower (in Farrah; 2012: 182) peer feedback refers to the suggestions or comments, questions or inquiries that learners offer each other after reading any piece of writing with the aim of producing 'reading based prose'. In line with Flower, Farrah (2012: 182) states that peer feedback refers to engaging learners in the process of sharing their ideas and receiving as well as offering constructive comments and suggestions for improving a piece of writing.

There are many procedures suggested by the researchers in conducting peer feedback technique. Some of them are the procedures suggested by Barkley, at all (2005: 251). They are:

1. Students work in pairs, taking turns describing ideas for the paper that each individually intends to write. Each students describes his or her 
ideas, a partner takes notes, asks question, and makes suggestion.

2. Each students conducts research for the individual paper, keeping an eye open for material that might prove useful to the partner

3. Students write their papers individually

4. Within each pair, students exchange paper drafts for peer editing. Student editors make proofing marks and comments directly on the paper and score or rate the paper with a peer review form. Student editors also complete and sign the peer review form, indicating their ratings of each of these elements.

5. Each author revises his or her paper, taking the peer editing into consideration

6. Author attaches the peer review form to the final draft and submits it to the professor for evaluation.

In line with above procedure

Paulus (in Hyland 2003: 93) provides some procedures of peer feedback. They are: (1) Teacher provides modeling and discussion of peer review at beginning of course; (2) Students are given peer review form; (3) students are paired based on oral language proficiency and different L1 (4) students write second draft after peer review.

Different form the process of peer feedback, teacher feedback is feedback on students writing given by their teacher. Teacher feedback in this study is focused on teacher written feedback that is proposed by Hyland (2003: 167).

According to Srichanyachon (2012: 8) teacher written feedback or handwritten commentary is a primary technique to respond to students' essays to assist students' writing development; teacher written comments on the students' drafts indicate problems and make suggestion for improvement of future papers. Through feedback teachers can help students compare their own performance with the ideal and to diagnose their own strengths and weaknesses.

The other factor influencing students' writing ability is creativity. There are some definitions of creativity. Kaufman and Sternberg (2006: 2) state that creativity involves thinking that is aimed at producing ideas or product that are relatively novel and that are, in some respect, compelling. Moreover, creativity is a means by which a person obtains a new perspective and as a result brings something new to consciousness (Rockler, 1988: 6). Marin in Kaufman and Stemberg (2006:79) defines creativity as an innovative process that requires coming up with something that didn't exist before, breaking the routine, being unexpected.

Aznar in Kaufman and Stemberg (2006: 78) believes that creativity is the ability to come up with new solutions without following a logical process, because the most important characteristic of creativity is the capacity to resolve problems by skirting them, or distancing oneself from the problem for a moment to tackle it from a different angle. He adds that the creative process follows these steps: Abandon the problem, look for stimuli, and link these stimuli with the problem. In addition, De la Torre (in Kaufman and Stemberg; 2006:72) defines that creativity is the capacity and willingness to generate new ideas and communicate them. Suharnan (2011:7) creativity is a thinking process to create new ideas, approaches, products that are useful for solving problem and environment. He adds that creativity must have a new aspect (idea, thought, activity, action or product and a useful aspect.

From the definitions above, it can be concluded that creativity is the 
people's thinking process and ability to create and generate new ideas, products, services, actions and processes that are useful. Briefly, it can be concluded that creativity has two main characteristics (new and useful).

\section{Research Methodology}

The research method used for this research was an experimental study. Experimental research is a research in which the researcher manipulates the independent variable. As stated by Johnson and Christensen (2000: 23), the purpose of experimental research is to determine cause-and-effect relationships. It means that the purpose of an experimental study is to investigate the correlation between cause and effect and how far its correlation is by giving certain treatment to experimental class and to control class as the comparison.

The population of this study is all of the tenth grade students of SMA Muhammadiyah 1 Metro. The total numbers of the population are 134 students divided into 6 classes. The writer used two classes which are randomly selected. The sampling technique applied in this study was cluster random sampling.

The research design used for the research is factorial design $2 \times 2$ by technique of multifactor analysis of variance (ANOVA).

Table 1. Factorial Design

\begin{tabular}{lll}
\hline $\begin{array}{l}\text { Technique/ } \\
\text { Creativity }\end{array}$ & $\begin{array}{l}\text { Peer } \\
\text { Feedback } \\
\left(\mathbf{A}_{1}\right)\end{array}$ & $\begin{array}{l}\text { Teacher } \\
\text { Feedback } \\
\left(\mathbf{A}_{2}\right)\end{array}$ \\
\hline High $\left(\mathbf{B}_{1}\right)$ & $\mathrm{A}_{1} \mathrm{~B}_{1}$ & $\mathrm{~A}_{2} \mathrm{~B}_{1}$ \\
Low $\left(\mathbf{B}_{2}\right)$ & $\mathrm{A}_{1} \mathrm{~B}_{2}$ & $\mathrm{~A}_{2} \mathrm{~B}_{2}$ \\
\hline
\end{tabular}

Where:

$\mathrm{A}_{1} \mathrm{~B}_{1}$ : Students having high creativity taught by using peer feedback technique

$\mathrm{A}_{2} \mathrm{~B}_{1}$ : Students having high creativity taught by using peer feedback technique
$\mathrm{A}_{1} \mathrm{~B}_{2}$ : Students having high creativity taught by using peer feedback technique

$\mathrm{A}_{2} \mathrm{~B}_{2}$ : Students having high creativity taught by using peer feedback technique

\section{Result Of The Research Hypothesis Testing}

Table 2. The Summary of a $2 \times 2$

Multifactor of Variance

\begin{tabular}{lccccc}
\hline $\begin{array}{l}\text { Source of } \\
\text { Variation }\end{array}$ & SS & Df & MS & $\mathbf{F}_{\text {obs }}$ & $\mathbf{F}_{\mathbf{t}(\mathbf{0 . 0 5})}$ \\
\hline $\begin{array}{l}\text { Between } \\
\text { column }\end{array}$ & 164.2045 & 1 & 164.2045 & 6.47 & 4.08 \\
$\begin{array}{l}\text { Between } \\
\text { rows }\end{array}$ & 121.1136 & 1 & 121.1136 & 4.77 & 4.08 \\
$\begin{array}{l}\text { Columns } \\
\text { by rows }\end{array}$ & 882.0227 & 1 & 882.0227 & 34.77 & 4.08 \\
\hline $\begin{array}{l}\text { Between } \\
\text { groups }\end{array}$ & 1167.341 & 3 & 386.3 & & \\
$\begin{array}{l}\text { Within } \\
\text { groups }\end{array}$ & 1014.545 & 40 & $\mathbf{2 5 . 3 6 3 6 4}$ & & \\
\hline $\begin{array}{l}\text { Total } \\
\text { Variance }\end{array}$ & 2181.886 & 43 & 50.74 & & \\
\hline
\end{tabular}

Based on the Table 2, it can be concluded that:

1. The result of the $F_{o}$ (between columns) is 6.47 and the $F_{t}$ at the level of significance $\alpha 0.05$ is 4.08 in which $F_{0}(6.47)$ is higher than $F_{t}(4.08)$. It means that the null hypothesis $\left(\mathrm{H}_{0}\right)$ is rejected. Then, it can be concluded that there is a significant difference between Peer Feedback Technique and Teacher Feedback Technique in teaching writing toward students' writing ability. Because the mean score of students taught by using Peer Feedback Technique (74.77) is higher than mean score of students taught by using Teacher Feedback Technique (70.91), it can be concluded that Peer Feedback Technique is more effective than Teacher Feedback Technique to teach writing for the tenth grade students of SMA Muhammadiyah 1 Metro

2. The result of the $F_{o}$ (between rows) is 4.77 and the $F_{t}$ at the level of significance $\alpha 0.05$ is 4.08 in which $F_{0}(4.77)$ is higher than $F_{t}$ (4.08). It means that the null hypothesis $\left(\mathrm{H}_{0}\right)$ is rejected. Then, it can be concluded that there is 
a significant difference between the students having high creativity and those having low creativity. Because the mean score of students having high creativity (74.5) is higher than mean score of students having low creativity (71.18), it can be concluded that the students having high level of creativity have better writing ability than those who have low creativity.

3 . The result of the $F_{o \text { (interaction) }}$ is 34.77 and the $F_{t}$ at the level of significance $\alpha 0.05$ is 4.08 in which $F_{o}$ (34.77) is higher than $F_{t}$ (4.08). It means that the null hypothesis $\left(\mathrm{H}_{0}\right)$ is rejected. It can be concluded that there is an interaction between teaching technique and students' creativity toward students' writing ability.

After knowing that there is an interaction between teaching techniques and students' creativity, Tuckey test is needed to know how significant the difference and interaction is.

Table 3. The Summary of Tuckey Test

\begin{tabular}{cccl}
\hline $\begin{array}{c}\text { Between } \\
\text { Group }\end{array}$ & $\boldsymbol{q}_{\mathbf{0}}$ & $\boldsymbol{q}_{\mathbf{t}}$ & Significance \\
\hline $\mathrm{A}_{1}-\mathrm{A}_{2}$ & 3.598 & 2.933 & Significant \\
$\mathrm{B}_{1}-\mathrm{B}_{2}$ & 3.090 & 2.933 & Significant \\
$\mathrm{A}_{1} \mathrm{~B}_{1}-\mathrm{A}_{2} \mathrm{~B}_{1}$ & 8.441 & 3.113 & Significant \\
$\mathrm{A}_{1} \mathrm{~B}_{2}-\mathrm{A}_{2} \mathrm{~B}_{2}$ & 3.353 & 3.113 & Significant \\
\hline
\end{tabular}

The finding of $\mathrm{q}$ is found by dividing the difference between the means by the square root of the ration of the within group variation and the sample size.

1. The difference of students writing ability between those taught by using Peer Feedback Technique and those taught by using Teacher Feedback Technique (Between $\mathrm{A}_{1}$ and $\mathrm{A}_{2}$ ) The result of the $q_{0}$ is 3.598 and the $q_{t}$ at the level of significance $\alpha 0.05$ is 2.933 in which $q_{0}$ (3.598) is higher than $q_{t}$ (2.933). It can be concluded that the students writing ability taught by using Peer Feedback Technique is significantly different from the students taught by using Teacher Feedback Technique. The students who are taught by using Peer Feedback Technique have better writing ability than students who are taught by using Teacher Feedback technique.

2. The difference of students writing ability between those who have high creativity and those who have low creativity (between $\mathrm{B}_{1}$ and $\mathrm{B}_{2}$ )

The result of the $q_{0}$ is 3.090 and the $q_{t}$ at the level of significance $\alpha 0.05$ is 2.933 in which $q_{0}$ (3.090) is higher than $q_{t}$ (2.933). It can be concluded that there is significance difference in writing ability between the students who have low level of creativity and students who have high level of creativity. The students who have high level of creativity have better writing ability than the students who have low level of creativity.

3. Experimental group compared to control group for the students having high creativity (Between $\mathrm{A}_{1} \mathrm{~B}_{1}$ $\mathrm{A}_{2} \mathrm{~B}_{1}$ )

The result of the $q_{0}$ is 8.441 and the $q_{t}$ at the level of significance $\alpha 0.05$ is 3.113 in which $q_{0}(8.441)$ is higher than $q_{t}$ (3.113). It can be concluded that teaching writing by using Peer Feedback technique to the students having high creativity is significantly different from the students having high creativity taught by using Teacher Feedback Technique. Because the mean of $A_{1} B_{1}(80.91)$ is higher than that of $A_{2} B_{1}$ (68.09), it can be concluded that Peer feedback technique is more effective than Teacher Feedback Technique to teach writing for students who have high level of creativity

4. Experimental group compared to control group for the students having low creativity (Between $A_{1} B_{2}-A_{2} B_{2}$ ) 
The result of the $q_{0}$ is 3.353 and the $q_{t}$ at the level of significance $\alpha 0.05$ is 3.113 in which $q_{0}$ (3.353) is higher than $q_{t}$ (3.113). It can be concluded that teaching writing by using Peer Feedback technique to the students having low creativity is significantly different from the students having low creativity taught by using Teacher Feedback Technique. Because the mean of $A_{2} B_{2}$ (73.73) is higher than that of $A_{1} B_{2}(68.64)$, it can be concluded that Teacher feedback technique is more effective than Peer Feedback Technique to teach writing for students who have low level of creativity

Reffering to the result of tuckey test at point 3 and 4 above, it can be stated that Peer Feedback Technique is more effective than Teacher Feedback Technique for teaching writing to the students having high creativity and Teacher Feedback Technique is more effective than Peer Feedback Technique for teaching writing to the students having low creativity, so it can be concluded that there is an interaction between teaching technique and students creativity for teaching writing.

\section{Discussion}

Based on the result of data analysis, it can be presented as follows:

1. Peer Feedback Technique is more effective than Teacher Feedback Technique to teach writing.

The different effect on the students' writing ability between those who are taught by using Peer Feedback Technique and those who are taught by using Teacher Feedback Technique can be seen from the result of ANOVA test. It shows that there is a significance difference of teaching technique. On the other hand, analyzed further from the result of Tuckey test shows the students writing ability taught by using Peer Feedback Technique is significantly different from the students taught by using Teacher Feedback Technique. The students who are taught by using Peer Feedback Technique have better writing ability than students who are taught by using Teacher Feedback Technique.

Feedback on students writing is an important aspect to develop students' language awareness and it is often seen as one of the ESL writing teacher's most important tasks (Hyland; 2003: 70). It will make the students realize and understand their deficiency in writing so that they can improve their writing. Peer feedback is an interactive process of reading and commenting on a classmate's writing. In this technique, the student pairs critically review and provide editorial feedback on each other's essays, reports, arguments, research papers, or other writing assignments. Peer feedback helps teach students how to identify the features of good and poor writing in the work of others, thus developing critical evaluation skills that they can apply to their own writing (Barkley et all; 2005: 4). Moreover, Peer feedback also can make students learn from other student and this reduces affective filters such as fear, shyness, and frustration.

The result can be significantly different because peer feedback technique focuses on student center. This technique allows the student to gain confidence, critical thinking skill from being able to read text by peer writing on similar tasks. Moreover by applying peer feedback, students learn by themselves, learn more, feel more confident feel more decided, enjoy the class, teach each other, and become 
independent learners. By using peer feedback in the teaching and learning, the students can use their own knowledge and share their knowledge with their friends. Besides that, they can interact with each other to solve problems. It also helps weaker students in learning. Related to writing, peer feedback is teaching techniques where students can work together in small group to help each other before they do independently. the most important Peer Feedback Techniques helps teach the students how to identify the features of good and poor writing in the work of others, thus developing critical evaluation skills that they can apply to their own writing.

Furthermore, peer feedback generates development of both the students as the writer and the students as the reader. Kurt and Atay (in Zainurrahman; 2010: 13) explain that in peer feedback students do not only compose their writing but also read their friends writing. In reading their friend writing, they are aware that their role is "error searcher" and this awareness makes them to carefully read their friends' writing. This is in line with Rolinson (in Zainurrahman: 2010: 13) who mentions that peer feedback also trains students to be critical reader. However, the importance pointed out here is that when the student critically and carefully read their friends' writing, it is possible that they find mistakes that similarly they made on their own writing. This emerges the students (as the reader) to make revision based on their self-awareness where the friends' writing becomes "mirror" that reflect their own writing. Therefore, the interaction and the negotiation in the peer feedback activity, as believed by social constructionist, generate benefit in two sides: writing and reading.
Different form the process of peer feedback, teacher feedback is feedback on students writing given by their teacher. Teacher feedback in this study is focused on teacher written feedback that is proposed by Hyland (2003: 167). Teacher feedback is another technique that the teaching and learning process focuses on the teacher. In this technique the students tend to be passive because the teacher has dominant figure. The interaction between the teacher and the students is usually in the form of one way communication form the teacher to the students. Moreover, students become recipient who absorbs the teacher's information. Moreover Kroll (2003: 199-123) acknowledges that teacher as writing instructor have to invest a great deal of time and energy in responding to students text and correcting them. He adds that students in worst case scenarios resent or event completely ignore the teachers markings and comments on their papers. Hyland (2003: 179) is also worried about whether students even understand the correction made by their teachers.

2. The students having high creativity have better writing ability than those having low creativity.

Creativity is known as people's thinking process and abilities to create and generate new ideas, product, services, actions and processes that are useful. Briefly, creativity has two main characteristics (new and useful). Everyone has a different level of creativity which affects their ways of thinking, their behavior, and their competences in all aspect of life. Based on this research, it is revealed that creativity plays an important role in helping students express their ideas in the written form especially in the form of recount text. From the data 
analysis, it shows that the students with high creativity have better writing ability. It is essentially important for students having high creativity because if they are creative they will be able to explore their creativity with the way they have in joining the teaching learning process.

Creativity plays an important role to produce a good and understandable writing. Creativity is the activity to convey something new. In other words, creativity involves thinking that is aimed at producing ideas of product that are relatively new (Kaufman and Sternberg, 2006: 2). Writing activity involves students' creativity since creativity can allow them to generate new ideas in solving an existing problem. In producing a piece of writing, the students need some creativity. According to Jones and Wyse (2004: 20) the composition of writing usually requires considerable amounts of creativity. It means that in producing a piece of writing, students need amount of creativity. It indicate that creativity determine students' writing ability.

The students having high level of creativity have better writing ability than those who have low creativity. It is because their creativity helps them to express and develop their idea and analyze their writing. The students with high level of creativity are able to involve both mental and social processes in order to yield newly developed ideas to convey and share. One's creativity can be seen in her/his eagerness to take part in an activity enthusiastically, to come up with new and fresh idea, to behave assertively, and to share with others.

On the other hand, the students with low level of creativity will just write what he sees, reads, and listens without being able to think what is beyond. They are unable to come up with their own fresh idea and opinions when learning. These are some of the reasons why their writing scores are less than those having high creativity. Their low creativity makes them unable to express their ideas better. This can be seen from the results of their wiring ability in which the scores of both control and experimental classes are lower than those of having high level of creativity from both classes given treatment.

3. There is an interaction between teaching techniques and students' creativity for teaching writing.

The interaction between teaching technique and students' creativity had been proved by the result of ANOVA test. The result of data analysis shows that there is an interaction between writing technique and students' creativity on writing ability. In addition, the result of Tuckey test point 3 and 4 describes that Peer Feedback Technique is suitable for students having high creativity and Teacher Feedback Technique is suitable for students having low creativity. In short, the effectiveness of teaching technique depends on students' level of creativity.

Peer feedback technique is an interactive process of reading and commenting on a classmate's writing. In this technique, teaching learning process focuses on student centered learning. The students' pairs critically review and provide editorial feedback on each other's writing. In this technique students tried to analyze their friends writing to give the useful feedback on his friend writing. In this process the students analyzed the text by considering the feature of good text and evaluate based on the content, organization, vocabulary, language use, and mechanics. This process 
stimulated the students' creativity and critical thinking in analyzing and giving feedback on the other's writing. This process need amount of creativity. De la Tore (Kaufman and Sternberg; 2006: 80) state that creativity is the capacity and willingness to generate and communicate new ideas, sensitive to the problem, correcting what doesn't work and returning to the use of patterns in order to come up with ideas. Those characteristic make the students easy to do the peer feedback technique that emphasize on the process of reading and commenting on the others writing and give them chance to share their knowledge, teach each other and become independent learner. Peer feedback technique needs the student to find the problems, mistakes, and weakness and solve the problem with the new ideas. For the students having high creativity, Peer feedback technique is more effective than teacher feedback technique in teaching writing because the students who have high creativity find no problem at all to come up with their fresh, original, and new ideas when they share and discuss with other sot that they can be more active.

On the contrary, teacher feedback is another technique that the teaching and learning process focuses on the teacher. In this technique the students tend to be passive because the teacher has dominant figure. The interaction between the teacher and the students is usually in the form of one way communication form the teacher to the students. Moreover, students become recipient who absorbs the teacher's information. Besides that, the students' scientific, creative thinking and critical thinking cannot be facilitated properly. For the students having low creativity, teacher feedback technique is better than Peer feedback technique in teaching writing because the students who have low creativity are helped by the tea her for developing their creative step by step. Reid (1993: 250) states that comments from the teacher help the students to get individual attention in their own needs or problems in writing. In this case, Peer Feedback technique is better for the students who have high creativity than those who have low creativity and teacher feedback technique is better for the students who have low creativity than those who have high creativity. Therefore, it can be concluded that there is an interaction between teaching technique and creativity for teaching writing.

\section{Conclusion, Implication, And Suggestion}

Based on the result of the research and discussion of the findings, the conclusions of the research are as follows:

1. In general, Peer Feedback Technique is more effective than Teacher Feedback Technique. Students taught by using Peer Feedback Technique have better Writing ability than those taught by using Teacher Feedback Technique for the tenth grade students of SMA Muhammadiyah 1 Metro.

2. In general, the students having high creativity have better writing ability than students who have low creativity for the tenth grade students of SMA Muhammadiyah 1 Metro.

3. There is an interaction between Teaching techniques and students' creativity to teach writing for the tenth grade students of SMA Muhammadiyah 1 Metro. The interaction happened because Peer Feedback Technique is more 
appropriate for students having high creativity, and Teacher Feedback Technique is more appropriate for students having low creativity.

Based on the result of the research, it implies that Peer Feedback is an effective teaching technique to improve students' writing ability for the tenth grade students of SMA Muhammadiyah 1 Metro. Peer feedback is an interactive process of reading and commenting on a classmate's writing. In this technique, the student pairs critically review and provide editorial feedback on each other's writing. Peer feedback helps teach students how to identify the features of good and poor writing in the work of others. It will develop their critical evaluation skills that they can apply to their own writing.

This technique allows the student to gain confidence, critical thinking skill from being able to read text by peer writing on similar tasks. Moreover, by applying peer feedback technique, students learn by themselves, teach each other, and become independent learners. The students can use their own knowledge and share their knowledge with their friends. Furthermore, peer feedback generates development of both the students as the writer and the students as the reader. Students do not only compose their writing but also read their friends writing. In reading their friend writing, they are aware that their role is "error searcher" and this awareness makes them to carefully read their friends' writing. It trains students to be critical reader. When the student critically and carefully read their friends' writing, it is possible that they find mistakes that similarly they made on their own writing. This emerges the students (as the reader) to make revision based on their self-awareness where the friends' writing becomes "mirror" that reflect their own writing. Therefore, the interaction and the negotiation in the peer feedback activity, as believed by social constructionist, generate benefit in two sides: writing and reading.

Based on the research finding, there are some important points which are addressed to the teachers, students, and other researcher as considerations in applying peer feedback technique. This technique emphasizes on the students active learning through the instruction that make students' responsible for the feedback that they give to other writers. This technique needs students' ability in finding the problem of their friend writing, correcting what doesn't work, communicating their ideas and teaching each other. Therefore, the teacher is expected to apply Peer Feedback Technique especially for the students with high creativity. In order to make students understand and make their feedback correct and useful, the teacher should introduce, train and give some guidelines before asking the students to conduct peer feedback. The teacher should give some exercises to train students' understanding to analyze the text correctly. Besides, the teacher also should consider that creativity is one of the internal factors from the students themselves that can influence their writing ability.

In order to make students easy to analyze their friend writing, they should try to know and comprehend the features of good and poor writing. The students also should to know the element of writing such as content, organization, vocabulary and mechanics as factors measured in writing. Moreover, for the students, since teaching technique is one of the factors that can influence their learning achievement, the students have to be more active in joining the English lesson in the classroom. The students should write the English text more. It will 
help them to practice their writing in order to improve their writing ability.

The readers are expected to conduct research about writing ability by using Peer Feedback Technique for the different population and by using different students' condition. It is used to enrich the theories in English teaching and support the effectiveness of peer feedback technique especially in teaching writing.

\section{References}

Barkley.E.F.,Cross.K.P., \& Major C.H. (2005). Collaborative Learning Techniques. San Francisco: Jossey-Bass.

Byrne, Donn. (1997). Teaching Writing Skills (Longman Handbooks for Language Teachers). Edinburgh Gate: Longman.

Depdiknas, (2005). Peraturan Pemerintah No. 19, 2005. Standar Nasional Pendidikan. Jakarta: Depdiknas.

Farrah, M. (2012). The Impact of Peer Feedback on Improving the Writing Skills among Hebron University Students. An-Najah Univ. J. Res. (Humanities). Vol 26 (1)

Ferris, Dana. 2003. Response to Student Writing (Implications for Second Language Students. New Jersey: Lawrence Erbaum Associates Publishers.

Hernowo. (2003). Quantum Writing. Bandung: Mizan Learning Center.

Hornby, A.S. (2010). Oxford Advance Learner's Dictionary Eighth Edition, International Studetns' Edition. New York: Oxford University Press.

Hyland, K. and F. Hyland. (2006). Feedback on Second Language Students' Writing. Cambridge: Cambridge University Press.
Hyland, Ken. (2003). Second Language Writing. New York: Cambridge University Press.

Jones, Rusell and Wyse, Dominic. 2004.

Creativity in the Primary

Curiculum. London: David Fulton Publisher

Kaufman, James C. \& Sternberg, Robert J. (2006). The International Handbook of Creativity. New York: Cambridge University Press.

Keh, Claudia L. (1990). Feedback in the Writing Process: a Model and Methods for Implementation. ELT Journal. Volume 44/4 October 1990. Oxford University Press.

Kroll, B. (2003). Exploring the Dynamics of Second Language Writing. Cambridge: Cambridge University Press.

Murcia, Celce, Marianne and Elite Olshtein. (2000). Discourse and Context in Language Teaching. New York: Cambridge University Press.

Nunan, David. (1998). Second Language Teaching and Learning. Boston: Heinle \& Heinle Publishers. .(2003). Practical English Language Teaching. Singapore: Mc. Graw Hill.

Oshima A. \& Hogue A. (2007). Introduction to Academic Writing $\left(3^{\text {rd }}\right.$ Edition). White Plains: Pearson Education. Inc.

Spratt, Mary and Alan. (2005). The Teaching Knowledge Test Course $(T K T)$. New York: Cambridge University Press.

Srichanyachon, Napaporn. (2012). Teacher Written Feedback for L2 Learners' Writing Development. Silpakorn University Journal of Social Sciences, Humanities, and Arts. Vol 12 (1): 7-17 
Suharnan. (2012). Kreativitas (Teori dan Pengembangan). Surabaya: Laros

Ur, P. (1996). A course in Language Teaching Practice Theory. Cambridge Teacher Training and Development. Cambridge: Cambridge University Press.

Zainurrahman. (2010). Peer Feedback: Students' Narrative Writing Development and Students' Response (A Case Study in an ESL Writing Classroom). Unpublished Thesis. Bandung: UPI Bandung. 